\title{
Creating Your Animated Stories with Plotagon: Implementation of Project-Based Learning in Narrative Writing
}

\author{
Senny Suzanna Alwasilah \\ Universitas Pasundan \\ Bandung, Indonesia
}

\begin{abstract}
In English as foreign language learning, writing is considered to be challenging since it requires more complex thinking than other language skills. Along with technology advancement, writing learning can embed technology to provide more learning opportunities. Therefore, this study seeks to investigate the benefits of the implementation of project-based learning in teaching narrative writing in university. By involving 40 students of the English Literature Department, Plotagon (a 3D animation-making software) was used in the 'Imaginative Writing' course to mediate a project that required students to visualize their own story in the form of animated films. This study employed a qualitative research method with a case study design. The results revealed that there were three benefits of implementation of project-based learning (PBL) in teaching writing: (1) PBL was a fun and humanistic learning assignment; (2) PBL provided the opportunity for students to learn in a real context; and (3) Plotagon was an appropriate application to mediate students in improving their multiliteracy abilities. As a pedagogical implication, PBL is a potential method to be implemented in a variety of learning styles, which can accommodate a variety of intelligence of each student in the future.
\end{abstract}

Keywords: Narrative Writing; Plotagon; Project-Based Learning.

\section{Introduction}

Writing is a process and a product in which in its activities, the authors are allowed to visualize, compile, edit, read, and reread (Nunan, 2003: 23). Its purpose is to communicate to readers when, where, and what happened to characters (Kamimura, 2016). Kirszner and Mandel (2008: 209) also state that writing is a process of arranging steps that involve: 1) planning, setting goals and generating ideas, and 2) organizing organizational information, selecting the appropriate language, compiling, revising, and editing. 
For most EFL students, writing is very difficult to master because it requires more complex thinking than speaking (Weigle, 2011). This evidence is in line with Richards and Renandya (2002), they argue that its difficulty does not only emerge in creating and arranging ideas, presenting ideas into readable texts becomes another issue to address. Therefore, the process of creating writing is a collaborative process that develops the symbolic relationship between authors, texts, and readers (Massi, 2001).

The existence of technology can be utilized as assisting tools in improving students' writing skills through an effective and innovative learning method. Project-Based Learning (PBL) is considered to be one of the effective solutions in teaching writing at any level, particularly at the college level (Jacobson, 2018). PBL performs as a more efficient method compared to the traditional ones as it helps students to adapt to different learning styles (Kaldi, Filippatou \& Govaris, 2011). In accordance, Bell (2010) states that the element of choice in PBL helps students to be successful in learning. Thus, it is believed that the students should get exposure to a wider variety of learning possibilities.

The implementation of PBL that integrates technological aspects into learning activities can provide more space to create dynamic learning process and opportunities for student to collaborate (Thomas \& Reinders, 2010), to provide flexibility to access learning outside the classroom (Kent \& Facer, 2004), and to obtain opportunities to increase creative and high-quality thinking ability (Boholano, 2017). This is in accordance with Grant (2011) who states that PBL offers a method that allows learning assignments to be authentic and fits in students' interests.

Creating an animated or digital story can be meaningful project activities for the students (Du, Chaaban, AlMabrd, 2019). By bringing it into the teaching aspects, students gain different experiences when learning writing. They can be taught to make stories, and develop them by visualizing their story through multimedia software resulted in animated movies. Plotagon application can be used to support this activity since it is a free online tool for Mac and PC that allows anyone to create animated film directly from the screenplay (Love, 2013). Through PBL in narrative learning that utilizes Plotagon, the learning process will become more meaningful. Therefore, the students can gain opportunities to develop other skills, e.g. multimedia, digital literacy, creativity, and even the thinking process, and practicing writing skills.

\section{Literature Review}

\subsection{Project-Based Learning and Narrative Writing}

The narrative is one of the basic discourse forms found in all cultures ( $\mathrm{Su} \&$ Chou, 2016). Narrative writing is generally driven by the goals of the characters (Garrard, 2011). Hyland (2011) affirms that there are three structural elements in a narrative story: orientation, complication, and resolution.

One of the appropriate methods in teaching narrative writing is project-based learning (PBL), which is a model organizing learning around doing a project. 
The learning takes place in groups requiring the students to perform complex tasks whose output is usually a concrete product (Kortam, Basheer, Hofstein, Hugerat, 2018). This type of method requires students to actively participate in the entire learning and teaching in which students will conduct a certain project (Thomas, 2000).

Therefore, in addition to creating reading texts, the learning process of narrative writing also aims at creating products, such as animation, short films, drama and so on. This activity makes learning more challenging, and it also requires students to think of how their writings can be visualized in other forms. In the end, this method mediates the process of language learning and knowledge through technological tools (Mishra and Kohler, 2006).

Furthermore, Tezi (2006) states that the final products, either good or bad, are produced by students, and they can learn and participate in the process. Stoller (2002) also explains that project work can be classified as part of cooperative learning because it allows students to work alone or work with their friends.

\subsection{Plotagon as Media for Implementing Project-Based Learning in Narrative Writing}

Many technological tools can be used to create the product in PBL, such as blogs, software, online web tool, and application for a smartphone. Even though PBL leads students to develop a project, but in the end, the priority is students' participation in the learning process (Tezi, 2006).

In narrative learning, students are encouraged to collaborating in creating a story, then visualizing their story/writing into a 3D animated movie. Practically, students are required to participate in collaborative learning in a group project using Plotagon as Love (2013) states that Plotagon can produce animated movies from screen dialogues. Meanwhile, the users do not require special animation skills in creating an animated video with Plotagon, and it only takes a few minutes to create an amazing animated movie.

This software has sophisticated features, such as selecting several characters simply, choosing their scene (schools, beaches, winter wonderland, etc.), typing words to create their characters speaking, and pressing the "Play" button to see if the written text shows an animated story (Aymerich-Franch, Kizilcec \& Bailenson, 2014). This software contains many characters, but the users can also create their own character versions too, choose several facial features, hairs, costumes, and accessories. Videos can be edited by adding emotions, actions, music, and sound effects through a simple pull-down menu (Love, 2013). 

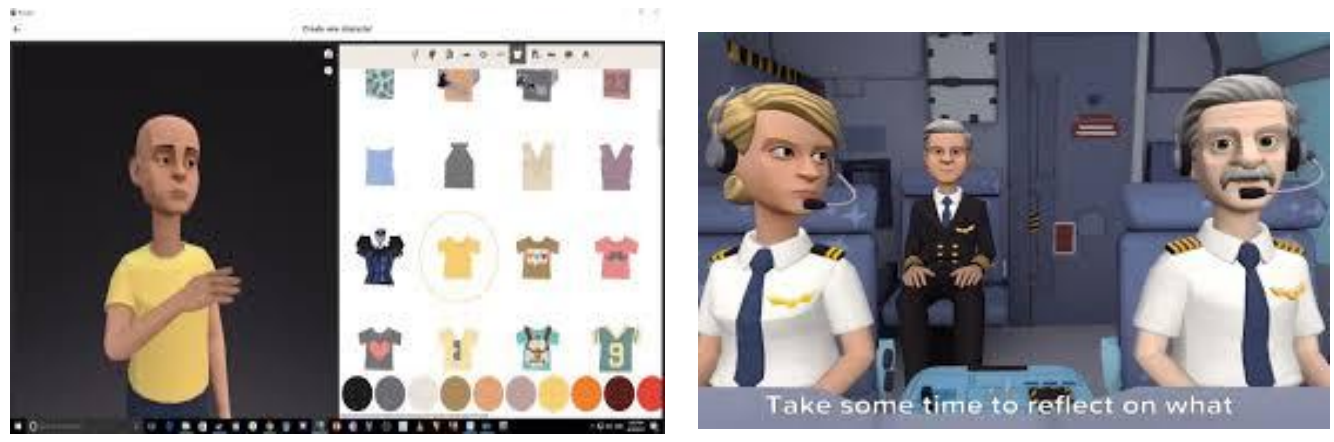

Figure 1. Character Creation in the Plotagon

This software can become an ideal media for developing PBL in narrative writing. The teachers can allow the students to explore technological tools, and guide them through these technological tools played in learning activities (Mishra and Kohler, 2006). Therefore, the process of learning is presented in a fun way, so that it can increase students' motivation, especially in learning to write.

\subsection{Research Backdrop}

Several studies on PBL advocated in English language teaching have been recorded. Hafner and Miller (2011) evaluated the potential of digital video projects for language learning of English for Science and Technology course at a university in Hongkong. A range of new technologies and Web 2.0 platforms (including YouTube and Edublogs) were integrated into the project process to enrich the learning process. This study found that digital video project could provide opportunities for autonomous language learning. The qualitative findings showed that students were engaged in a $21^{\text {st-century task utilizing }}$ multimodal texts, media, and online environments that were meaningful to them.

Saputro (2013) did an experimental study on the use of digital storytelling in improving students' mastery of writing narrative. His study involved eight graders students of one junior high school in Grobogan, East Java, Indonesia. After the treatment, the mean of the experimental group was higher than the control group. In other words, there was a significant difference in the achievement of students in which they were exposed to digital storytelling than those who learned using a conventional technique. Therefore, it infers that the use of digital storytelling as a visual aid can enhance students' mastery in narrative writing.

Besides, Kessler, Bikowski, and Boggs (2012) investigated the role of the Webbased project in mediating students' collaborative writing for academic purposes. The study revealed that the students successfully collaborated in groups and developed their process towards writing. The students were engaged in a collaborative writing project using Web-based word processing tools focused on meaning over form as they created their texts. 
Poonpon (2017) explored the students' opinions about how the implementation of PBL in the form of the interdisciplinary-based project in a language classroom. It aimed at encouraging the students to apply their language skills and knowledge of their specific field of study and to complete a task, as PBL has the potential to enhance the students' language skills. The empirical data showed that the students believed the project was successfully improved their English skills in real-life contexts.

Further, Dooly and Sadler (2016) examined the potential use of technology and Computer-Mediated Communication (CMC) for an integrated approach to Project-Based Learning. The findings also indicated that the Project-Based Language Learning approach (PBLL) allowed the students to gain new information about the topic under study used to communicate face-to-face with their classmates and online (with telecollaborative partners). The results showed that project-based learning was able to help the students to produce the target language set by the teacher as the core curricular in the learning process.

Gámez and Cuellar (2019) conducted a study entitled 'The Use of Plotagon to Enhance the English Writing Skills in Secondary School Students". It is action research involving 18 tenth grade students of a public secondary school in Columbia. The findings revealed that Plotagon has successfully promoted students' motivation to write through digital stories. As a result, the students increased their vocabulary and improved their English writing skills. This study also signified the role of Plotagon as a pedagogical tool to enhance students' English writing in a fun and meaningful way.

Zakaria, Yunus, Nazri, and Shah (2016) conducted a study on the use of digital storytelling. They utilized the use of Storybird platform in 15 diploma students of a private university in Malaysia. The findings showed that most respondents reflected their positive experiences in using Storybird in writing ESL narrative text, which significantly implies that Storybird is an appropriate pedagogical tool to teach English.

Those aforementioned studies have signified the importance of enhancing writing skills through PBL using digital pedagogical tools. However, there have not been any studies that specifically explored narrative writing learning for university students that employ PBL using Plotagon. Therefore, this study seeks to address this gap by involving students of the English Literature Department taking the 'Imaginative Writing' course to learn narrative in-depth using Plotagon. This study becomes significant as it elaborates on the implementation of narrative learning through detailed stages with the utilization of Plotagon through PBL. In other words, this study contributes to providing step-by-step stages of narrative learning to enhance university students' writing skills.

\section{Research Method}

This research employs a qualitative method aiming at investigating the quality of relationships, activities, situations, or materials by emphasizing the holistic 
description (Alwasilah, 2011; Creswell, 2013). This qualitative method used a case study because this research's characteristic is suitable. First, this research only investigated a single unit (Ary, Jacobs, Sorensen \& Razavieh, 2010), namely a class of English Literature students of the 'Imaginative Writing' course. Second, it sought to investigate a phenomenon in its real context (Liamputtong, 2009; Yin, 2011), in meaning observing how PBL works in the context of classroom learning. In this research, the phenomenon was that a lecturer taught writing narratives through PBL. Furthermore, the case to be investigated was the benefits of implementing students' learning methods in narrative writing.

\subsection{Research Site and Participant}

This research was conducted in one of the universities in Bandung City, West Java. The participants were 40 English Literature students who were in their Spring semester taking the 'Imaginative Writing' course in 2019/2020 Academic Year. This study became feasible since the author was the lecturer teaching this particular course. In addition, this specific class was suitable to be involved in this study since narrative learning is appropriate to be learned and taught in the 'Imaginative Writing' course.

\subsection{Research Design}

This students' project was conducted during the Spring Semester of 2019/2020 Academic Year in 16 meetings. The workflow of the students' project is presented in Table 1 below.

Table 1. The Workflow of Students' Project

\begin{tabular}{|c|c|c|}
\hline Meeting & Stage & Type(s) of Activity \\
\hline $1-2$ & $\begin{array}{l}\text { Brainstorming } \\
\text { the story idea }\end{array}$ & $\begin{array}{l}\text { - The lecturer explained the narrative text, } \\
\text { the generic structure, and the composition } \\
\text { of narrative text. } \\
\text { - The students sought references regarding } \\
\text { the types of narrative-genre stories. } \\
\text { - The students discussed the creation of story, } \\
\text { plot, characters/characterization, story } \\
\text { setting, and storyline. } \\
\text { - The students discussed the conflict and } \\
\text { resolution of the story. } \\
\text { - The students discussed the making of moral } \\
\text { value in their stories. }\end{array}$ \\
\hline $3-5$ & $\begin{array}{l}\text { Drafting the } \\
\text { story }\end{array}$ & $\begin{array}{l}\text { - The students collaborated on the draft story. } \\
\text { - Each group provided suggestions and } \\
\text { comments towards the draft story compiled } \\
\text { by each group. }\end{array}$ \\
\hline $6-8$ & $\begin{array}{l}\text { Writing the } \\
\text { story }\end{array}$ & $\begin{array}{l}\text { - The students collaborated in compiling the } \\
\text { story in } 4,000 \text { words. } \\
\text { - Each group provided suggestions and } \\
\text { comments towards the draft story compiled } \\
\text { by each group. }\end{array}$ \\
\hline $9-10$ & $\begin{array}{l}\text { Editing the } \\
\text { story }\end{array}$ & $\begin{array}{l}\text { - Each group reviewed the story from } \\
\text { another group. }\end{array}$ \\
\hline
\end{tabular}


$11-13$

\begin{abstract}
Creating the
\end{abstract} animation

- Each group was required to provide corrective feedback towards the story from another group, consisting of grammar, vocabulary, storyline, conflict, and resolution.

- The lecturer provided corrective feedback towards the story from another group.

- The lecturer re-checked the edited students' story.

- The lecturer introduced the Plotagon software.

- The students learned the mechanics of the Plotagon software.

- The students visualized their story into the 3D animation by using the Plotagon software.

- The students collaborated in determining the music background, choosing a place setting based on their stories, and creating the characters.

- The students created the 5-minutes animated film.

14-16 Presenting the - Presenting the students' animation product products.

- Reflecting on the learning that had been conducted.

This project required the students to create a 5-minutes animation. In the beginning, they were asked to make a story consisting of 4,000 words related to the teenagers' anxiety. Each story should only have four characters and was obliged to provide strong moral values to provide positive values and develop social sensitivity. The themes taken in the stories made by each group are as follows:

1. A person's turmoil in determining majors in college

2. The friendship that leads to a love triangle story

3. Family conflict regarding differences in children's dreams and parents' ambitions

4. The dilemma of being a superstar

5. Story of a successful teenager

\subsection{Data Collection and Data Analysis}

The data collection methods used for this study included observation, interviews, and online artifacts. The class observation was used to know the implementation of PBL using Plotagon in the process of writing actual narrative texts. The researcher served as the participant-observer because she taught students in writing class. She observed the class and took notes into an observation checklist during the classroom learning with the assistance of the video recorder to capture other phenomena that were not obtained during 
observation and note-taking. The observation was done during the whole 16 meetings to collect in-depth and detailed data during the learning process.

The semi-structured interviews were conducted using Bahasa Indonesia and English so that the students could answer the question with comfort. There were six students representing low-achiever, mid-achiever, and high-achiever classification. The purpose of this interview was to obtain students' perception and experience regarding the use of Plotagon in their narrative learning activities. The online artifact analysis was conducted to examine the narrative products written by students in groups. In this research, the data were taken from screenshots of films produced by the students using Plotagon. The following Table 2 is the rubric used to examine students' project work.

Table 2. The Rubric of Students' Assessment

\begin{tabular}{|c|c|c|c|}
\hline $\begin{array}{l}\text { Retells story in } \\
\text { correct } \\
\text { sequence } \\
\text { leaving out no } \\
\text { essential parts } \\
\text { of stories. }\end{array}$ & $\begin{array}{l}\text { Retells story in } \\
\text { sequence with } \\
2-3 \text { omissions. }\end{array}$ & $\begin{array}{l}\text { Retells story } \\
\text { with several } \\
\text { omissions, but } \\
\text { maintains the } \\
\text { sequence of } \\
\text { those told. }\end{array}$ & $\begin{array}{l}\text { Retells story } \\
\text { out of } \\
\text { sequence. }\end{array}$ \\
\hline $\begin{array}{l}\text { Uses a varied } \\
\text { appropriate } \\
\text { vocabulary for } \\
\text { the audience, } \\
\text { and also } \\
\text { successfully } \\
\text { tries to enlarge } \\
\text { the audience's } \\
\text { vocabulary. }\end{array}$ & $\begin{array}{l}\text { Uses a varied } \\
\text { appropriate } \\
\text { vocabulary for } \\
\text { the audience. }\end{array}$ & $\begin{array}{l}\text { Uses a varied } \\
\text { vocabulary that } \\
\text { is occasionally } \\
\text { a little too } \\
\text { simple or a } \\
\text { little too hard } \\
\text { for the } \\
\text { audience. }\end{array}$ & $\begin{array}{l}\text { The vocabulary } \\
\text { was not varied, } \\
\text { OR was } \\
\text { routinely } \\
\text { inappropriate } \\
\text { for the } \\
\text { intended } \\
\text { audience. }\end{array}$ \\
\hline $\begin{array}{l}\text { Lots of vivid, } \\
\text { descriptive } \\
\text { words are used } \\
\text { to tell the } \\
\text { audience when } \\
\text { and where the } \\
\text { story takes } \\
\text { place. }\end{array}$ & $\begin{array}{l}\text { Some vivid, } \\
\text { descriptive } \\
\text { words are used } \\
\text { to tell the } \\
\text { audience when } \\
\text { and where the } \\
\text { story takes } \\
\text { place. }\end{array}$ & $\begin{array}{l}\text { The audience } \\
\text { can figure out } \\
\text { when and } \\
\text { where the story } \\
\text { took place, but } \\
\text { there isn't } \\
\text { much detail } \\
\text { (e.g., once } \\
\text { upon a time in } \\
\text { a land far, far } \\
\text { away). }\end{array}$ & $\begin{array}{l}\text { The audience } \\
\text { has trouble } \\
\text { telling when } \\
\text { and where the } \\
\text { story takes } \\
\text { place. }\end{array}$ \\
\hline $\begin{array}{l}\text { The storyboard } \\
\text { is complete } \\
\text { with sketches } \\
\text { for each scene, } \\
\text { detailed notes } \\
\text { on titles, } \\
\text { transitions, } \\
\text { special effects, } \\
\text { sound, etc. The } \\
\text { storyboard } \\
\text { reflects } \\
\text { outstanding }\end{array}$ & $\begin{array}{l}\text { The storyboard } \\
\text { is relatively } \\
\text { complete with } \\
\text { sketches for } \\
\text { most scenes, } \\
\text { and notes on } \\
\text { titles, } \\
\text { transitions, } \\
\text { special effects, } \\
\text { sound, etc. The } \\
\text { storyboard } \\
\text { reflects }\end{array}$ & $\begin{array}{l}\text { The storyboard } \\
\text { has glaring } \\
\text { omissions in } \\
\text { scene planning. } \\
\text { There are some } \\
\text { sketches, and } \\
\text { notes on titles, } \\
\text { transitions, } \\
\text { special effects, } \\
\text { sound, etc. The } \\
\text { storyboard } \\
\text { reflects }\end{array}$ & $\begin{array}{l}\text { The storyboard } \\
\text { is not done or } \\
\text { is so } \\
\text { incomplete that } \\
\text { it could not be } \\
\text { used even as a } \\
\text { general guide. } \\
\text { The storyboard } \\
\text { reflects very } \\
\text { little planning } \\
\text { of the visuals. }\end{array}$ \\
\hline
\end{tabular}




\begin{tabular}{|c|c|c|c|}
\hline $\begin{array}{l}\text { planning and } \\
\text { organization } \\
\text { for the visuals } \\
\text { in the video. }\end{array}$ & $\begin{array}{l}\text { effective } \\
\text { planning and } \\
\text { organization } \\
\text { for the visuals } \\
\text { in the video. }\end{array}$ & $\begin{array}{l}\text { attempts at } \\
\text { planning and } \\
\text { organization } \\
\text { for the visuals } \\
\text { in the video. }\end{array}$ & \\
\hline $\begin{array}{l}\text { Connections } \\
\text { between } \\
\text { events, ideas, } \\
\text { and feelings in } \\
\text { the story are } \\
\text { creative, } \\
\text { clearly } \\
\text { expressed, and } \\
\text { appropriate. }\end{array}$ & $\begin{array}{l}\text { Connections } \\
\text { between } \\
\text { events, ideas, } \\
\text { and feelings in } \\
\text { the story are } \\
\text { clearly } \\
\text { expressed and } \\
\text { appropriate. }\end{array}$ & $\begin{array}{l}\text { Connections } \\
\text { between } \\
\text { events, ideas, } \\
\text { and feelings in } \\
\text { the story are } \\
\text { sometimes } \\
\text { hard to figure } \\
\text { out. More } \\
\text { detail or better } \\
\text { transitions are } \\
\text { needed. }\end{array}$ & $\begin{array}{l}\text { The story } \\
\text { seems very } \\
\text { disconnected, } \\
\text { and it is } \\
\text { challenging to } \\
\text { figure out the } \\
\text { story. }\end{array}$ \\
\hline $\begin{array}{l}\text { The length of } \\
\text { the video was } 5 \\
\text { minutes. }\end{array}$ & $\begin{array}{l}\text { The length of } \\
\text { the video was } \\
4 \text { minutes. }\end{array}$ & $\begin{array}{l}\text { The length of } \\
\text { the video was } 3 \\
\text { minutes. }\end{array}$ & $\begin{array}{l}\text { The video was } \\
\text { less than } 3 \\
\text { minutes long } \\
\text { OR more than } \\
5 \text { minutes. }\end{array}$ \\
\hline $\begin{array}{l}\text { The script is } \\
\text { complete, and } \\
\text { it is clear what } \\
\text { each actor will } \\
\text { say and do. } \\
\text { Entries and } \\
\text { exits are } \\
\text { scripted, as are } \\
\text { important } \\
\text { movements. } \\
\text { The script is } \\
\text { quite } \\
\text { professional. }\end{array}$ & $\begin{array}{l}\text { The script is } \\
\text { mostly } \\
\text { complete. It is } \\
\text { clear what each } \\
\text { actor will say } \\
\text { and do. The } \\
\text { script is shows } \\
\text { planning. }\end{array}$ & $\begin{array}{l}\text { Script has a } \\
\text { few major } \\
\text { flaws. It is not } \\
\text { always clear } \\
\text { what the actors } \\
\text { are to say and } \\
\text { do. The script } \\
\text { shows an } \\
\text { attempt at } \\
\text { planning but } \\
\text { seems } \\
\text { incomplete. }\end{array}$ & $\begin{array}{l}\text { There is no } \\
\text { script. Actors } \\
\text { are expected to } \\
\text { invent what } \\
\text { they say and } \\
\text { do as they go } \\
\text { along. }\end{array}$ \\
\hline
\end{tabular}

In particular, the process of data analysis was analyzed using an interpretative approach (Bernard, 2000), which aims at interpreting people's experiences and the situation in conducting a writing project. The first step was coding the data using the data-driven coding approach. The data should be analyzed on an ongoing basis. The next step was labeling and grouping the data into a theme so that the data could be explained clearly and in detail. Furthermore, triangulation was conducted to confirm the data obtained from each instrument so that the potential bias in this research could be reduced, thus each data could be related to each other.

\section{Findings}

This section discusses the findings and discussion of data regarding the benefits of implementing the project-based learning method in narrative writing. Based on the results of instrument analysis, there were three classifications of themes, including: (1) PBL is a fun and humanistic learning assignment, (2) PBL provides the opportunity for students to learn in a real context, and (3) Plotagon is an 
appropriate application to mediate students in improving their multiliteracy abilities.

\subsection{The Project of Making Animation Becomes a Fun and Humanistic Learning Assignment}

One of the benefits of this method was because of its formative evaluation. In addition to obtaining an interesting learning method, the students also had the opportunity to get an assessment of learning outcomes without going through a written test. The aspects of assessment did not only focus on cognitive assessment, but also performance, cooperation, aesthetics, and the creative process in making more humanistic learning assignment.

The observation data showed that convenience in the learning process made them be able to exert the best potential. The students were enthusiastic about participating in the learning session. On the other hand, they also obtained an interesting assignment in accordance with their world. This factor was important in supporting learning success, besides increasing learning motivation. With fun and humanistic assignment, of course, the students would be interested in participating actively in the learning process, between in-class discussions, activities outside the classroom, and participation in project work.

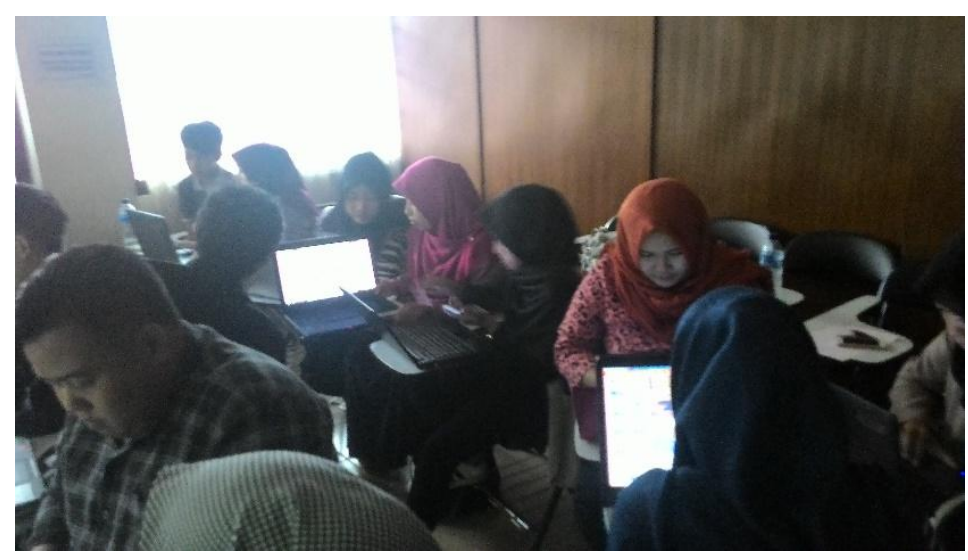

Figure 2. Students' Enthusiasm during Discussions

The findings from the interview section supported the fact that the students had a positive impression on the forms of the assignment given by the lecturer. They believed that the project work made them very challenged to exert all their best abilities. Moreover, the students believed that the form of assessment given was fair. They had the opportunity to provide maximum efforts in learning, and simultaneously receive constructive feedback through project work. Following are the excerpts of interviews with students

\section{Interview with the Student I:}

"I feel the lecturer's assessment of our work is very fair and wise so that I feel comfortable in doing the assignments given by my lecturer." 


\section{Interview with the Student II:}

"I am happy that the lecturer provided us with a variety of tasks to accomplish from week to week. I am thrilled to be challenged since we were assessed fairly."

The assessment of the students' project products showed that their results were very good. The collaboration was the most essential factor in helping the students understand their learning materials. The elementary errors in students' animation products rarely occurred, either in terms of language or editing. In terms of languages, errors in the use of grammar, word choice, and making sentences occurred rarely. Moreover, the students had been able to compose sentences well, even in simple sentences.

PBL created an atmosphere that emphasized the aspects of humanity and warmth in the learning process. The classroom became the initial establishment of the learning pattern that also emphasized the importance of social interaction compared to academia (Bell, 2010). Practically, all students were willing to participate in the collaborative learning process and cooperate with each other (Vygotsky, 1978 cited in Jarvis, 2005).

\subsection{PBL Provides the Opportunity for Students to Learn in a Real Context}

By implementing PBL in learning writing, the lecturer had the opportunity to provide varied assignments that would help students understand the learning material. In relation to students' animation project, the variety of assignments given by the lecturer include discussion, collaborative writing, editing, evaluations with peer students, and product publication and presentation. These also could be found in the data obtained from the observations. The variety of activities and assignments were designed so that students obtained a form of assignment that was authentic and close to the daily context. In addition, the students were able to use language skills in the real context. They also got the opportunity to acquire useful skills in the language.

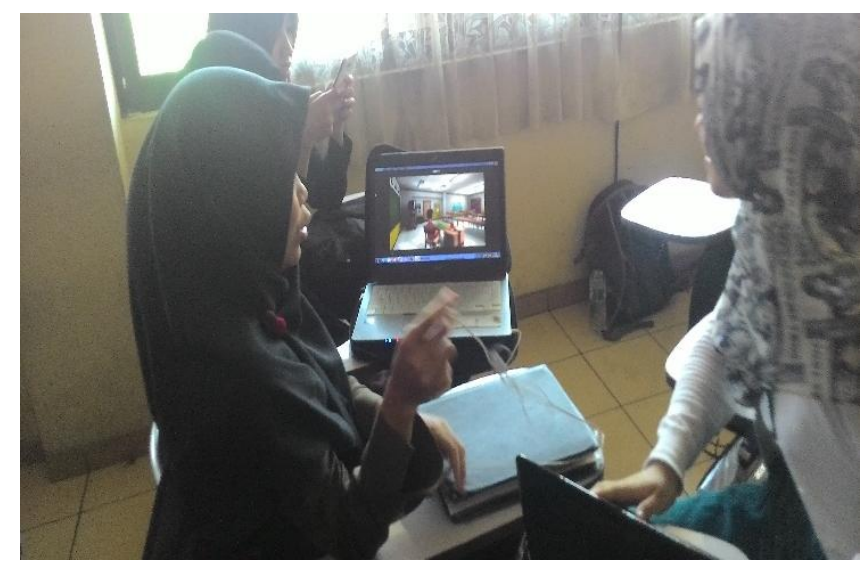

Figure 3. Students Discussing the Creation of Animation Using Plotagon

Furthermore, authentic material and assignments were needed to provide descriptions and insight related to the skills for the students to gain the skills 
needed in the future. They got more space to grow their writing skills through a variety of meaningful learning activities. The data from the interview process showed that students realized that they were working in a real context, as well as in accordance with the world and daily context. It was considered as a trigger for students to be more motivated in learning, increase perseverance in learning, increases enthusiasm in participating in the class. Following are the excerpts of the interviews:

Interview with the Student III:

"I am excited. When doing the assignment, I did not have anxiety and fear of getting a bad result. I become very confident, and want to study harder."

\section{Interview with the Student IV:}

"The topics to be developed into a story is related to our experience, so I can say that we learn narrative through real context."

One of the keys to success in implementing PBL in the classroom is the choice of topics (Habók, 2015). Topics must be chosen based on students' interests and preferences. This is fundamental to bring students closer to their world, and to maintain their enthusiasm for learning because PBL used the project as the learning process (Thomas, 2000).

\subsection{The Plotagon in an Appropriate Application to Mediate Students in Improving Their Multiliteracy Abilities}

The paradigm shift from traditional literacy to multiliteracy was intended to accommodate the presence of technology in learning activities. Multiliteracy is an interconnection among semiotic modes forming multimodal texts, including writing, visual, audio, gesture, and spatial. In addition to having the ability to write and read as in traditional literacy, the students also required the ability to criticize, interact, synthesize, and process information from various sources and media.

The activity of transforming and visualizing story into the form of animation trained the students to get used to using various media. They also had the opportunity to improve their high order thinking skills, because it was not easy to transform the story into an animation. In the process of creation, the students were required to transform the story into the screenplay. Furthermore, they chose the characters in accordance with their story, inserted background music, determined background and setting of the story, and gave motions and effects to the characters, so that it could animate the story.

This process was conducted to train the students' thinking process, thus they were able to adapt to various multimodal media. The limitation of the Plotagon that was only able to present two characters in one scene became a challenge for the students. They must be able to animate the story with two characters in that scene. Through the creation of this project mediated by Plotagon, they were also required to make the appropriate dialogue, and describe their stories. This helped them improve their communication skills well. 


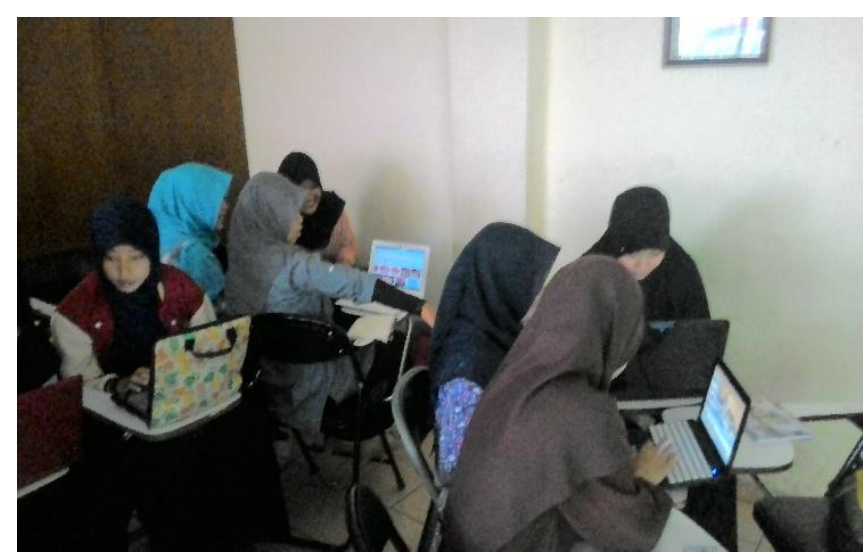

Figure 4. Students Discussing the Dialogue-Making Using Plotagon

The results revealed that the students gave positive responses to this learning activity. They realized that there were many inputs obtained from this writing course. Through PBL, they acquired additional skills, such as improving aesthetics, creating content using digital tools, and practicing the interaction process with multimodal media. Following are the excerpts of the interviews:

\section{Interview with the Student V:}

"I can say that Plotagon is a suitable tool to learn digital narrative writing."

\section{Interview with the Student VI:}

"Visualizing our story into animation is very interesting, despite the adjustment we did and the limitation of the application."

The results of students' products showed that the students obtained satisfactory results. Based on the results obtained from five groups, there was only a group that obtained the below-average result. It indicated that the students were able to show good performance in the classroom.

\section{Discussion}

This present study reported the benefits of implementing the project-based learning method in narrative writing. First, PBL makes learning more fun and humanistic. The classroom became the initial establishment of the learning pattern that also emphasized the importance of social interaction compared to academia (Bell, 2010).

Second, PBL provides the opportunity for students to learn in a real context. In their comments, students emphasized that project-based learning gave them opportunities to see connections between their courses and future careers, and life situations (Thompson, Eodice, \& Tran, 2015). One of the keys to success in implementing PBL in the classroom is the choice of topics for conducting a project (Habók, 2015). Choosing and selecting an appropriate topic becomes one of the essential factors in implementing PBL in the classroom activities. Further, topics must be chosen based on students' interests and preferences. This is very 
important to bring students closer to their world, and maintain their enthusiasm for learning because PBL used the project as the learning process (Thomas, 2000).

The last, Plotagon is an appropriate application to mediate students in improving their multiliteracy abilities. The data showed that the students gave positive responses to the use of Plotagon as a media for creating a digital story. In this present study, the process of creating a digital story project helped the students to enhance their multiliteracy skills. Angay-Crowder, Choi, \& Yi (2013) also revealed the use of the digital story might benefit from helping the learners to enhance their language and multiliteracy skills. Yeh (2018) comes to the conclusion that multimodal language learning is aimed at building autonomous learning, and creating flexibility in designing assignments. Moreover, the aspect of multimodality can also train and develop the students' communication skills (Hafner, 2013; Hafner \& Miller, 2011).

The emergence of technology, the internet, and digital tools allow for a shift in 21 $1^{\text {st }}$-century education (Borsheim, Merritt, \& Reed, 2008). For that reason, teaching English that merely focuses on linguistic aspects is not appropriate. Teachers need to facilitate the students in the use of language content in various contexts. In today's era, the languages are expressed through different kinds of media, involving: pictures, short messages, video clips or animations. In this present study, students were using their familiar tools. This evidence implied that most students believed that creating a digital story project was a meaningful activity for them. They also voiced that this project empowered their learning experience as well as their self-confidence in expressing their ideas.

Digital story project, in particular, enables students to build and enhance critical creativity and self-expression. By providing students with more opportunities to compose digital work in the PBL setting, students can capitalize on their thinking and creative proficiency. Moreover, the learning process of narrative writing is not only purposed for creating reading texts, but also creating products, such as animation, short films, drama, and so on. This study revealed that this activity made learning more challenging. It required the students to think about how their writings can be presented in another form, such as digital animated stories. In the end, this method mediates the process of language learning and knowledge through technological tools (Mishra and Kohler, 2006).

\section{Conclusion}

Writing is the most challenging skill to acquire, especially in the EFL context. Therefore, in facing 21st-century learning,the society should be prepared to master literacy skills that denote digital advances. Narrative learning can be used as one of the aids to help students enhance their multiliteracy and social skills. By employing PBL that integrates technology, narrative learning can be developed into making digital storytelling. Plotagon, an animation maker application, is believed to be appropriate to address the needs. 
By utilizing Plotagon, the students of the English Literature Department had 16 weeks of exposure to narrative writing with digital touch in their classroom. Its implementation was carried out with the foundation of PBL that signifies collaborative work. The findings revealed that there were three aspects of success in conducting PBL in narrative learning using Plotagon: (1) The development of multiliteracy during the learning process; (2) Students' opportunities to practice the ability to think virtuously and to visualize their stories into animation; and (3) Spaces for the lecturer to set a variety of studentbased assignments and learning. However, this can be successful when the learning facilities are adequate, and students obtain an optimal understanding of the use of the technological device. As an implication, the implementation of PBL through the utilization in narrative writing using Plotagon can accommodate social interaction, varied learning styles, and intelligence of each student.

\section{References}

Alwasilah, A. C. (2011). Pokoknya Kualitatif [Qualitative, That's All]. Jakarta: Pustaka Jaya.

Angay-Crowder, T., Choi, J., \& Yi, Y. (2013). Putting Multiliteracies into Practice: Digital Storytelling for Multilingual Adolescents in a Summer Program. TESL Canada Journal, 30(2), 36-45. doi:10.18806/tesl.v30i2.1140

Ary. D., Jacobs, L. C., Sorensen, C. K., \& Razavieh, A. (2010). Introduction to research on education (Eight editions). Belmont, California: Wadsworth Cengage Learning.

Aymerich-Franch, L., Kizilcec, R. F., \& Bailenson, J. N. (2014). The relationship between virtual self-similarity and social anxiety. Frontiers in Human Neuroscience, 8, 1-10. doi:10.3389/fnhum.2014.00944

Bell, S. (2010). Project-Based Learning for the 21st century: skill for the future. The Cleaning House, 83(2), 39-43. doi:10.1080/00098650903505415

Bernard, H. R. (2000). Social Research Methods: Qualitative and Quantitative Approaches. Thousand Oaks, CA: Sage. Communications Authority of Kenya (2015): Quarter Statistics Report of January 2015.

Boholano, H. B. (2017). Smart Social Networking: 21st Century Teaching and Learning Skills. Research in Pedagogy, 7(1), 21-29. doi:10.17810/2015.45

Borsheim, C., Merritt, K., \& Reed, D. (2008). Beyond Technology for Technology's Sake: Advancing Multiliteracies in the Twenty-First Century. Clearing House: A Journal of Educational Strategies, Issues and Ideas, 82, 87-90. doi:10.3200/TCHS.82.2.87-90

Creswell, J. W. (2013). Qualitative inquiry and research design: Choosing among five approaches (3rd ed.). Thousand Oaks, CA: Sage.

Dooly, M., \& Sadler, R. (2013). Filling in the Gaps: Linking Theory and Practice through Telecollaboration in Teacher Education. ReCALL, 25(1), 4-29. doi:10.1017/S0958344012000237

Du, X., Chaaban, Y., \& Mabrd, Y. A. (2019). Exploring the Concepts of Fidelity and Adaptation in the Implementation of Project-Based Learning in the Elementary Classroom: Case Studies from Qatar. International Journal of Learning, Teaching and Educational Research, 18(9), 1-22.doi:10.26803/ijlter.18.9.1

Gámez, D. Y. G. \& Cuellar, J. A. M. (2019). The Use of Plotagon to Enhance the Students Writing Skills in Secondary School Students. Profile: Issues in Teachers' Professional Development, 21(1), 139-153. doi:10.15446/profile.v21n1.71721. 
Garrard, D. (2011). A Case Study to Evaluate the Effectiveness of Digital Storytelling as a Narrative Writing Tool. https://ulir.ul.ie/bitstream/handle/10344/1818/2011_Garrard\%2cD.pdf?seque nce $=6$

Grant, M. M. (2011). Getting a Grip on Project-Based Learning: Theory, Cases, and Recommendations. Meridian: A Middle School Computer Technologies Journal, 5(1), 1-17. Retrieved from https:// meridian.ced.ncsu.edu/archive/win2002/514/project-based.pdf

Habok, A. (2015). Implementation of a Project-based Concept Mapping Developmental Programme to Facilitate Children's Experiential Reasoning and Comprehension of Relations. European Early Childhood Education Research Journal, 23(1), 129-142. doi:10.1080/1350293X.2014.991100

Hafner, C. A., \& Miller, L. (2011). Fostering learner autonomy in English for science: A collaborative digital video project in a technological learning environment. Language Learning \& Technology, 15(3), 68-86. doi:10125/44263

Hafner, C. A. (2014). Embedding digital literacies in English language teaching: Students' digital video projects as multimodal ensembles. TESOL Quarterly, 48(4), 655-685. doi:10.1002/tesq.138

Hyland, K. (2011). Genre and second language writing. Ann Arbor, MI: University of Michigan Press.

Jarvis M. (2005). The Psychology of Effective Learning and Teaching. Cheltenham: Nelson Thornes Ltd.

Kaldi, S., Filippatou, D., \& Govaris, C. (2011). Project-based learning in primary schools: Effects on pupils' learning and attitudes. Education 3-13, 39(1), 35- 47.

Kanter, D. E., \& Konstantopoulos, S. (2010). The impact of a project-based science curriculum on minority student achievement, attitudes and carreers: The effects of teacer content and pedagogical content knowledge and inquiry-based practices.

Kamimura, T. (2016). Skilled and unskilled Japanese EFL student writers' narrative story production. Journal of Pan-Pacific Association of Applied Linguistics, 20(1), 3754.

Kent, N., \& Facer, K. (2004). Different worlds? A comparison of young people's home and school ICT use. Journal of Computer Assisted Learning, vol. 20, pp. 440-455. doi:10.1111/j.1365-2729.2004.00102.x

Kessler, G., Bikowski, D. \& Boggs, J. (2012). Collaborative Writing among Second Language Learners in Academic Web-based Projects. Language Learning $\mathcal{E}$ Technology, 16(1), 91-109. doi:10125/44276

Kirszner, L. G., \& Mandell, R. S. (2008). The Pocket Wadsworth Handbook. Boston: Wadsworth

Kortam, N., Basheer, A., Hofstein, A., \& Hugerat, M. (2018). How Project-Based Learning promotes $7^{\text {th }}$-grade students' motivation and attitudes towards studying biology. Action Research and Innovation in Science Education, 1(2), 9-17.

Kuh, G. D. (2008). High-Impact Educational Practices: What They Are, Who Has Access to Them, and Why They Matter. Washington, D.C.: Association of American Colleges and Universities.

Liamputtong, P. (2009). Qualitative Research Method. Australia: Oxford University Press.

Love, D. (2013, November 25). Turning your students into movie directors with Plotagon [Web log post]. Retrieved from https://digiteacher.wordpress.com/2013/11/25/turning-your-students-intomovie-directors-with-plotagon/ 
Massi, M. P. (2001). Interactive Writing in the EFL Class: A Repertoire of Tasks. The Internet TESL Journal, 7(6). Retrieved from http://iteslj.org/Techniques/MassiWritingTasks.html

Mishra, P., \& Koehler, M. J. (2006). Technological Pedagogical Content Knowledge: A new framework for teacher knowledge. Teachers College Record, 108(6), 1017-1054. doi:10.1111/j.1467-9620.2006.00684.x

Nunan, D. (2003). Practical English Language Teaching. Singapore: McGraw Hill.

Poonpon, K. (2011). Enhancing English Skills through Project-based Learning. The English Teacher, 40(1), 1-10. Retrieved from https://journals.melta.org.my/index.php/tet/article/view/258

Richards, J., \& Renandya, W. A. (2002). Methodology in Language Teaching; AN Anthology of Current Practice. Cambridge: Cambridge University Press.

Saputro, D. A. J. (2013). Digital Storytelling to Improve Students' Mastery in Writing Narrative. English Language Teaching Forum, 2(1), 1-8. doi:10.15294/elt.v2i1.1554

Stoller, F. L. (2002). Project-Work: A Means to Promote Language and Content. In J. C. Richards, \& W. A. Renandya, Methodology in Language Teaching: An Anthology of Current Practice (pp. 107-120). Cambridge: Cambridge University Press.

Su, I-R., \& Chou, Y-C. (2016). L1-L2 Transfer in the Narrative Styles of Chinese EFL Learners' Written Personal Narratives. Taiwan Journal of TESOL, 13(2), 1-34.

Tezi, L. (2006). The Use of Project-Based Learning in Teaching English to Young Learners. A thesis. Konya: Sosyal Bilimler Enstitüsü, Seljuk University.

Thomas, J. W. (2000). A Review of Research on Project-Based Learning. Retrieved April 5, 2016, from http:/ / www.bobpearlman.org/BestPractices/PBL.Research.pdf.

Thomas, M. and Reinders, H. (2010). (Eds.). Task-based language learning and teaching with technology. London \& New York: Continuum.

Thompson, C. A., Eodice, M., \& Tran, P. (2015). Student Perceptions of General Education Requirements at a Large Public University: No Surprises?. The Journal of General Education, 64(4), 278-293. doi:10.1353/jge.2015.0025

Weigle, S. C. (2011). Assessing Writing (7th edition). Cambridge: Cambridge University Press.

Yeh, H. C. (2018). Exploring the perceived benefits of the process of multimodal video making in developing multiliteracies. Language Learning $\mathcal{E}$ Technology, 22(2), 2837. https://doi.org/10125/44642

Yin, R. K. (2011). Qualitative Research from Start to Finish. New York: Guilford Press.

Zakaria, S., Yunus, M., Nazri, N., \& Shah, P. (2016). Students' Experience of Using Storybird in Writing ESL Narrative Text. Creative Education, 7, 2107-2120. doi:10.4236/ce.2016.715210 